\title{
CONCENTRATION OF INJETION SOLUTION AND ITS EFFECTS ON SOIL AND ON YIELD OF FERTIRRIGATED BANANA CV TERRA MARANHÃO
}

\section{EUGÊNIO F. COELHO ${ }^{1}$, TORQUATO M. DE ANDRADE NETO ${ }^{2}$, DAMIANA L. BARROS 3}

\begin{abstract}
The Fertigation is the combined application of water and nutrients to a crop. It can be adapted to all types of agricultural crops. The objective of this study was to evaluate the effect of urea concentration in irrigation water on electrical conductivity of the soil solution and saturation extract along the first cycle of banana cv. Terra Maranhão. The experiment followed a completely randomized design with six treatments and ten replications. Treatments regarded for using three urea concentrations (1.0; 2.5 and $4.0 \mathrm{~g} \mathrm{~L}^{-1}$ ) in irrigation water applied by two micro irrigation systems (microsprinkler and drip). Results showed that there was a linear elevation of electrical conductivity of saturation extract and soil solution with the increase on concentration of urea in the injection solution. Urea should be used under concentrations up to $2.5 \mathrm{~g} \mathrm{~L}^{-1}$ in irrigation water without causing increase on electric conductivity of soil solution and saturation extract, considering $1.1 \mathrm{dS} \mathrm{m}^{-1}$ as the tolerated value for the crop. Nitrate in the soil solution increased significantly with the increase of urea concentration in the injection solution. The maximum concentration of nitrate in the soil occurred for $4,0 \mathrm{~g} \mathrm{~L}^{-1}$ concentration of the injection solution.
\end{abstract}

KEYWORDS: urea, salinity, fertirrigation.

\section{CONCENTRAÇÕES DA SOLUÇÃO DE INJEÇÃO E SEUS EFEITOS NO SOLO E NA PRODUTIVIDADE DA BANANEIRA-DA-TERRA MARANHÃO FERTIRRIGADA}

RESUMO: A fertirrigação é a aplicação combinada de água e nutrientes para a cultura. Ela pode ser adaptada a todos os tipos de culturas agrícolas. Objetivou-se pelo presente estudo avaliar o efeito da concentração de ureia na água de irrigação sobre a condutividade elétrica da solução do solo e do extrato de saturação ao longo do primeiro ciclo da cultura da bananeira-da-terramaranhão. O experimento seguiu um delineamento inteiramente casualizado, com seis tratamentos e dez repetições. Os tratamentos consistiram no uso de três concentrações $\left(1,0 ; 2,5\right.$ e 4,0 g L L ${ }^{-1}$ de ureia, aplicadas via gotejamento e microaspersão. Os resultados demonstraram uma tendência linear de elevação da condutividade elétrica do extrato de saturação e da solução do solo com o aumento da concentração da ureia na solução de injeção. A ureia pode ser usada em concentrações de até 2,5 $\mathrm{g} \mathrm{L}^{-1}$ na água de irrigação sem causar elevações na condutividade elétrica da solução do solo e do extrato de saturação acima do valor considerado adequado à cultura de $1,1 \mathrm{dS} \mathrm{m}^{-1}$. À medida que se aumentou a concentração da solução de injeção, aumentou significativamente o teor de $\mathrm{NO}_{3}{ }^{-}$no solo, com máximos para concentrações de $4,0 \mathrm{~g} \mathrm{~L}^{-1}$.

PALAVRAS-CHAVE: ureia, salinidade, fertirrigação.

\section{INTRODUCTION}

The Fertirrigation is a technique that combines the application of water with fertilizers through certain irrigation systems. The use of this technique has made it possible to optimize the use of inputs in different irrigated crops, both in aspects related to productivity and the quality of the obtained products, being most notable its adoption in irrigated crops by localized irrigation

\footnotetext{
${ }^{1}$ Embrapa Mandioca e Fruticultura Tropical, Rua Embrapa, s/nº Caixa Postal 007, CEP 44380-000 Cruz das Almas, BA, eugenio@cnpmf.embrapa.br

${ }^{2}$ Eng $^{\circ}$ Agrônomo, Doutor em Ciências Agrárias, Cruz das Almas-BA, andradeneto@hotmail.com

${ }^{3}$ Graduanda em Agronomia, Universidade Federal do Recôncavo a Bahia, damibarros@hotmail.com 
systems (Oliveira et al systems., 2008 (OLIVEIRA et al., 2008). Proper management should be used in order to maintain the values below the acceptable limits of soil salinity. Soil salinity has negative consequences for agricultural crops. About 900 million hectares are affected by salts (FAGERIA et al., 2010). Monitoring the soil salinity becomes crucial especially where fertirrigation is practiced. This misguided technique can raise the salinity of the soil, even if temporarily. The electrical conductivity of the soil can be used to quantify the salts in the soil. For purposes of fertirrigation electrical conductivity (EC) can be expressed as electrical conductivity of the soil solution $\left(\mathrm{EC}_{\mathrm{W}}\right)$ in unsaturated conditions and the electrical conductivity of the saturation extract $\left(\mathrm{EC}_{\mathrm{se}}\right)$, that is the CE of the soil solution when saturated. Studies using EC have pointed out their potential for measuring the nutrient content in the soil solution (ANDRADE NETO et al., 2012).

The effects of salinity on plants may be caused by the difficulty in water absorption, and toxicity of specific ions by interference of salts in the physiological processes (indirect effects), reducing the growth and development of plants (DIAS \& BLANCO, 2010). This is because a higher salt concentration in the soil solution results in greater competition for water between the plant and the salts (osmotic effect), which impairs the essential metabolic processes of plants. The negative effect on plant development by salinity is due to the difficulty to absorbing water, the toxicity of the ions involved and the physiological effects caused by salts (GHEYI et al., 2010). The rational management of fertirrigation has give attention to monitoring the concentration of fertilizer in irrigation water and the injection solution. Different concentrations of salt in irrigation water provide different levels of electrical conductivity of the soil solution and the saturation extract. In this sense, promoting the direct monitoring of salinity in the root zone is recommended to evaluate the current situation and the effectiveness of various management programs in irrigated areas. Accordingly, the electrical conductivity of the stratum saturation (ECss) and soil solution (EC $\mathrm{W}_{\mathrm{W}}$ are presented as tools to be used in monitoring the fertirrigation. Electrical conductivity values at certain levels can cause a decrease in productivity (BLANCO et al., 2008).

Among the most commonly used nitrogen sources are urea and ammonium sulfate. Nitrogen participates in various compounds considered essential for the growth and development of plants, especially proteins and chlorophyll (TAIZ \& ZEIGER, 2009). Nitrate constitutes one of the inorganic forms of nitrogen in the soil and, together with the ammonia constitutes the final product of the mineralization of organic nitrogen. The objective of the present study was to evaluate the effect of the concentration of calcium nitrate and urea in the irrigation water on the electrical conductivity on soil solution, the saturation extract and nitrate content during the first cycle of the banana cv. Terra.

\section{MATERIAL AND METHODS}

The study was conducted in the experimental field of Embrapa Cassava and Tropical Fruits, located in Cruz das Almas - BA (12 ${ }^{\circ} 48^{`} \mathrm{~S}$; $\left.39^{\circ} 06^{`} \mathrm{~W} ; 225 \mathrm{~m}\right)$. The climate is classified as humid to sub-humid with an average annual rainfall of $1,143 \mathrm{~mm}$. The soil of the experimental area is classified as Oxisol with free texture. Featuring humidity corresponding to field capacity and the permanent wilting point of $0.2312 \mathrm{~m}^{3} \mathrm{~m}^{-3}$ and $0.1645 \mathrm{~m}^{3} \mathrm{~m}^{-3}$, respectively

TABLE 1. The chemical characteristics of the soil at the beginning of the experiment.

\begin{tabular}{ccccccccc}
\hline $\mathrm{pH}$ & $\mathrm{P}$ & $\mathrm{K}$ & $\mathrm{Ca}+\mathrm{Mg}$ & $\mathrm{Na}$ & $\mathrm{H}+\mathrm{Al}$ & $\mathrm{S}$ & $\mathrm{CTC}$ & $\mathrm{V}$ \\
\cline { 2 - 9 } & $\mathrm{mg} \mathrm{dm}$ & \multicolumn{7}{c}{$\mathrm{cmolc} \mathrm{dm}^{-3}$} \\
\hline 6.3 & 11.0 & 0.06 & 3.4 & 0.09 & 1.32 & 3.56 & 4.88 & 73 \\
\hline
\end{tabular}

* Analysis conducted by Embrapa Cassava and Tropical Fruit

Banana cv.Terra Maranhão was planted in single rows $3.00 \mathrm{~m}$ x $2.50 \mathrm{~m}$. The experiment was installed with three concentrations of urea (1.0, 2.5 and $\left.4.0 \mathrm{~g} \mathrm{~L}^{-1}\right)$ and two trickle irrigation systems (drip and micro-sprinkler) as a completely randomized experiment design in a factorial $3 \times 2$, with 
10 replications. The treatment means were compared by t test at $5 \%$ probability. The micro sprinkler system consisted of an emitter flow $43.0 \mathrm{~L} \mathrm{~h}^{-1}$ for four plants; the drip irrigation system involved a lateral line per plant row, with three emitters of $4.0 \mathrm{~L} \mathrm{~h}^{-1}$ per tussock of plants. The depth of irrigation water replacement between two irrigations was calculated by crop evapotranspiration estimated from A pan evaporation method. Fertirrigation occurred in a weekly frequency where the solution volume (water and solutes) and concentration of the injection solution was determined as recommended by COELHO (2009). Samples of the solution injection were collected in the solution tank and outlets of the emitters on the fertirrigation days. The irrigation time for micro sprinkler system was: 1 hour and 20 minutes; 33 minutes and 20 minutes respectively for concentrations of 1.0; 2.5 and $4.0 \mathrm{~g} \mathrm{~L}^{-1}$. In the drip system, the average time for irrigation was 58 minutes; 24 minutes and 14 minutes, respectively for concentrations of 1.0; 2.5 and $4.0 \mathrm{~g} \mathrm{~L}^{-1}$. Samples of soil solution were collected monthly at each plot for monitoring soil electrical conductivity (ECs), using water samplers installed near the dripper at depths of 0.20 and $0.40 \mathrm{~m}$. Soil sample was also collected for for monitoring soil electrical conductivity of the saturation extract (ECs)at $0.30 \mathrm{~m}$ of plant near the dripper, with three replications per plot. The samples were collected with a Dutch auger type 0.030 $\mathrm{m}$ diameter, air-dried, and sieved on $0.002 \mathrm{~m}$ mesh. Then saturation paste was processed following EMBRAPA (1997) methodology from which was obtained the saturation extract that was used for determining the electrical conductivity using a table electrical conductivity meter. The solution samples were analyzed in kits of quick read "Horiba Card" for reading nitrate content. The kit was initially calibrated using solutions of known concentrations, presenting reliability of using, as COELHO et al. (2014) (Figure 1).

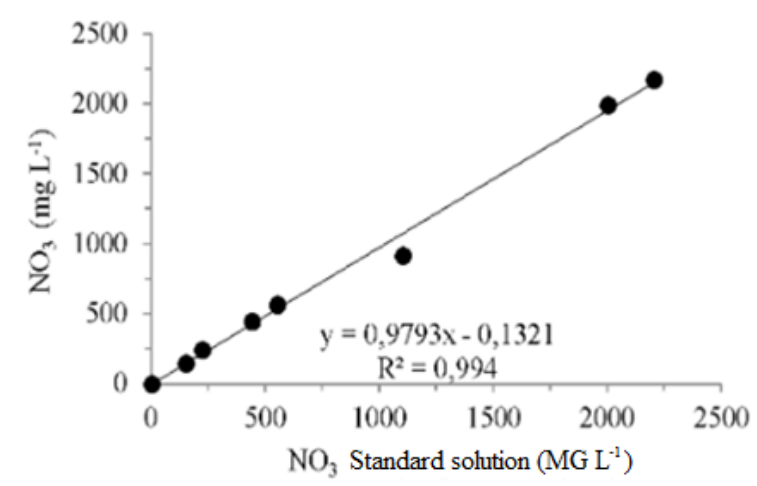

FIGURE 1. Calibration curve of the device Horiba Card.

Plant height, pseudo stem diameter at $0.20 \mathrm{~m}$ from soil surface and total leaf area (LA) were evaluated for growth analysis. Leaf area was estimated from the reading of the length and width of third leaf according to ALVES et al. (2010). Measurements of variables production were: productivity of hands, number of fruit per bunch, length and the diameter of the median fruit of the second hand. Average soil solution electrical conductivity and saturation extract as a function of urea concentrations were subjected to regression analysis and were compared between the irrigation systems by the Tukey test at $5 \%$ probability.

\section{RESULTS AND DISCUSSION}

Except for the concentration of $1.0 \mathrm{~g} \mathrm{~L}^{-1}$ there were no significant differences between means of $\mathrm{EC}_{\mathrm{se}}$ or $\mathrm{EC}_{\mathrm{s}}$ observed for the two irrigation systems. As for $\mathrm{EC}_{\mathrm{se}}$ under concentration of $1 \mathrm{~g} \mathrm{~L}^{-1}$, the absolute averages for micro sprinkler system were superior to the averages obtained for the drip system. It was observed that for both systems the average $\mathrm{EC}_{\mathrm{s}}$ was equal to 0.9 times the $\mathrm{EC}_{\mathrm{se}}$. These results are similar to those found by COSTA et al (2009). This superiority of $\mathrm{EC}_{\mathrm{se}}$ was also observed by (SANTANA et al., 2006). 
TABLE 2. Electrical conductivity averages of the saturation extract $\left(\mathrm{EC}_{\mathrm{se}}\right)$ and soil solution $\left(\mathrm{EC}_{\mathrm{s}}\right)$, fertirrigated with urea by drip and micro sprinkler system.

\begin{tabular}{ccccc}
\hline Urea & \multicolumn{2}{c}{ ECse $\left(\mathrm{dS} \mathrm{m}^{-1}\right)$} & \multicolumn{2}{c}{ ECs $\left.(\mathrm{dS} \mathrm{m})^{-1}\right)$} \\
\cline { 2 - 5 } Concentration & Micro & Drip & Micro & Drip \\
\hline $1.0 \mathrm{~g} \mathrm{~L}^{-1}$ & $0.5399^{\mathrm{a}}$ & $0.3784^{\mathrm{b}}$ & $0.5850^{\mathrm{a}}$ & $0.5264^{\mathrm{a}}$ \\
$2.5 \mathrm{~g} \mathrm{~L}^{-1}$ & $0.7743^{\mathrm{a}}$ & $0.7469^{\mathrm{a}}$ & $0.6993^{\mathrm{a}}$ & $0.6732^{\mathrm{a}}$ \\
$4.0 \mathrm{~g} \mathrm{~L}^{-1}$ & $1.0016^{\mathrm{a}}$ & $1.0521^{\mathrm{a}}$ & $0.9339^{\mathrm{a}}$ & $0.9547^{\mathrm{a}}$ \\
\hline
\end{tabular}

* Letters compare irrigation systems at each depth.

There were linear increases in electrical conductivity of the saturation extract and soil solution as concentration of urea increased (Figure 2). For both electrical conductivities the angular coefficient of the linear function was higher for drip indicating greater increase in electrical conductivity per unity increase in the concentration of the solution in relation to micro sprinkler system. The effect of ions concentration in the soil solution or in the saturation extract resulting from the application of an ionic or saline solution is more pronounced on drip, since the solution is concentrated in a smaller volume of soil compared to micro sprinkler. The data of the electrical conductivity in the saturation extract $\left(\mathrm{EC}_{\mathrm{se}}\right)$ and soil solution $\left(\mathrm{EC}_{\mathrm{s}}\right)$ during the crop cycle, showed no continuous increase or decrease with time in any of the two systems studied (Figure 3 ). The values of the electrical conductivities $\mathrm{EC}_{\mathrm{se}}$ and $\mathrm{EC}_{\mathrm{s}}$ were higher for the concentration of $4.0 \mathrm{~g} \mathrm{~L}^{-1}$ followed by concentrations of 2.5 and $1.0 \mathrm{~g} \mathrm{~L}^{-1}$. The increase on concentration of the fertilizer in irrigation water corresponded to the increases in the $\mathrm{EC}_{\mathrm{s}}$ and $\mathrm{EC}_{\mathrm{se}}$.

The electrical conductivity of the soil solution $\left(\mathrm{EC}_{\mathrm{s}}\right)$ and saturation extract $\left(\mathrm{EC}_{\mathrm{se}}\right)$ were above $1.1 \mathrm{dS} \mathrm{m}^{-1}$ at irrigation water concentration of $4.0 \mathrm{~g} \mathrm{~L}^{-1}$ in both micro sprinklers and drip, in part of the crop cycle. The use of this concentration may cause damage to the crop as under drip as under micro sprinkler where $50 \%$ and $33 \%$ of the data of $E_{\text {se }}$ exceed $1.1 \mathrm{dS} \mathrm{m}^{-1}$, respectively, based upon the recommendation that the cultivation of banana should be done in soil with electrical conductivity of the saturation extract below $1.1 \mathrm{dS} \mathrm{m}^{-1}$ (OLIVEIRA, 1999). Banana is a glycophyte plant and therefore very sensitive to soil salinity (OLIVEIRA et al., 2000). The recommendation of OLIVEIRA (1999) is very close to those of other authors (DOOREMBOS \& KASSAN, 1983; SILVA, 2002). DOOREMBOS \& KASSAN (1983) claimed that banana need soil with $\mathrm{EC}_{\mathrm{se}}<1.0$ $\mathrm{dS} \mathrm{m} \mathrm{m}^{-1}$. Based on these latter authors we should be careful with the concentration of $4.0 \mathrm{~g} \mathrm{~L}^{-1}$, which resulted in values of $\mathrm{EC}_{\mathrm{se}}$ higher than $1.0 \mathrm{dS} \mathrm{m} \mathrm{m}^{-1}$, in large part of the crop cycle for the two irrigation systems. ISRAELI et al. (1986), however, found average levels of salinity of water and soil of 3.6 and $3.0 \mathrm{dS} \mathrm{m}$, respectively, to cause delay in growth and decline in the banana production. No analysis of concentrations reached near the track of $3.0 \mathrm{dS} \mathrm{m}^{-1}$.

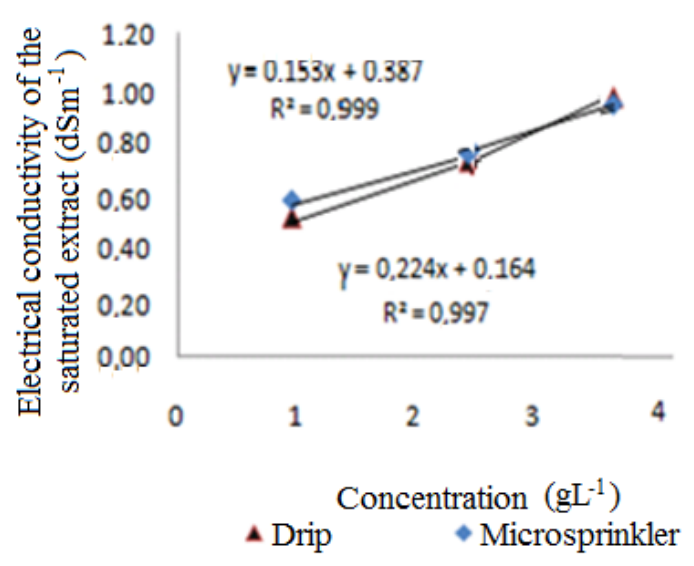

(a)

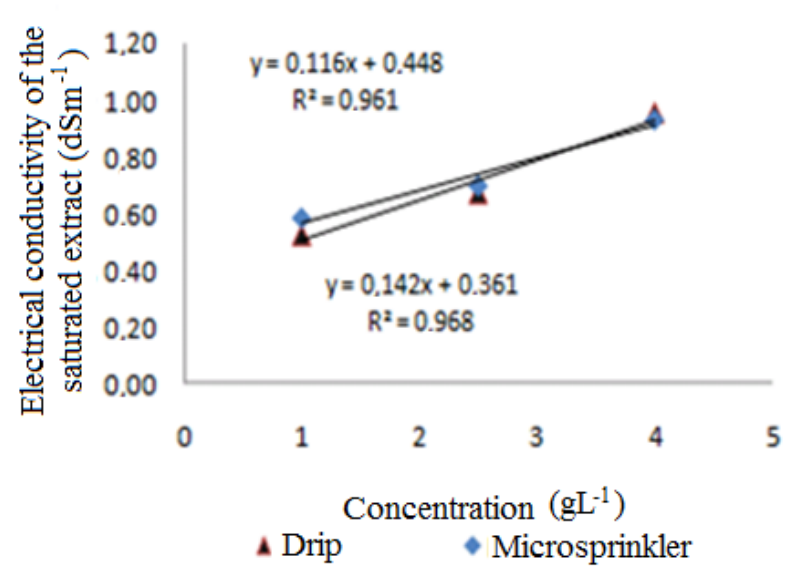

(b)

FIGURE 2. Electrical conductivity of the saturation extract (a) and soil solution (b) as a function of concentration of the inject solution. 


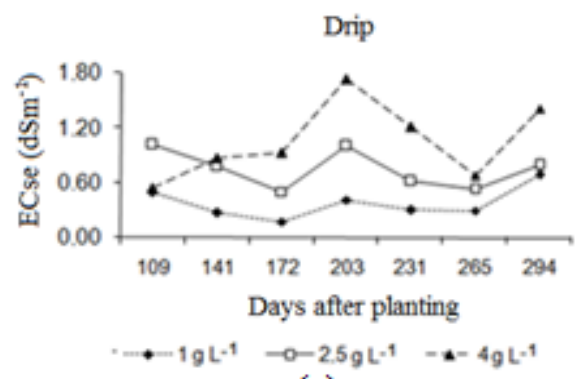

(a)

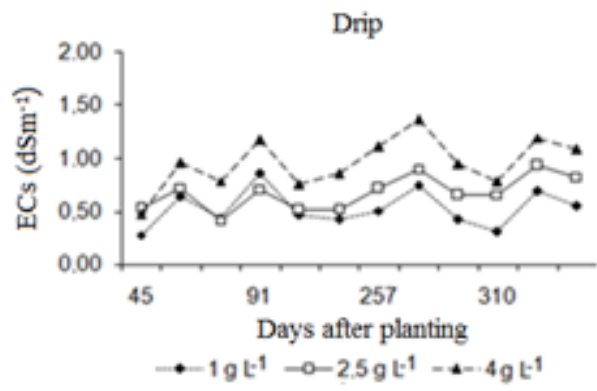

(c)

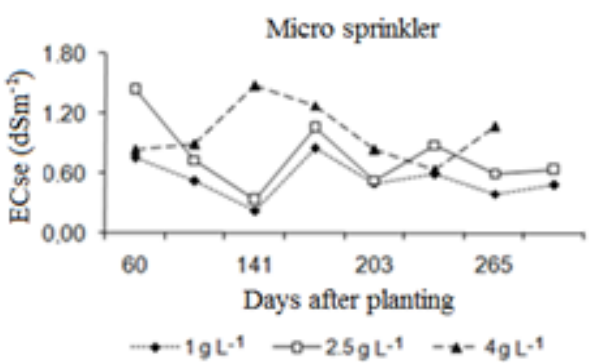

(b)

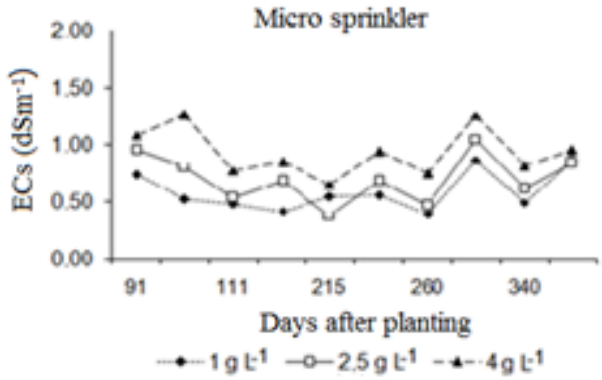

(d)

FIGURE 3. Values of electrical conductivity of the saturation extract (a and b), the soil solution (c and d), for fertirrigation with urea in two irrigation systems (drip and micro sprinkler).

As concentration of urea increased in the irrigation water, increased the concentration of $\mathrm{NO}_{3}{ }^{-}$ in the soil solution following a linear relation (Figure 4) in both drip and micro-sprinkler system. The linear relation explains the variation of the nitrate concentration as a function of the injection solution concentration into the soil in the depth of $0.20 \mathrm{~m}$ (Figure 4a) compared to the depth of 0.40 $\mathrm{m}$ (Figure 4b). At a depth of $0.20 \mathrm{~m}$ the nitrate concentration showed a rate of increase 3.79 times the rate at the depth of $0.40 \mathrm{~m}$ for the drip. In the micro sprinkler system, the rate at $0.20 \mathrm{~m}$ depth was 2.09 times the rate of $0.40 \mathrm{~m}$. A similar result was reported by LI et al. (2003) who have worked with different nitrate concentrations in irrigation water. According to these authors, the concentration of nitrate in the soil solution was directly affected by the concentration of the injection solution.

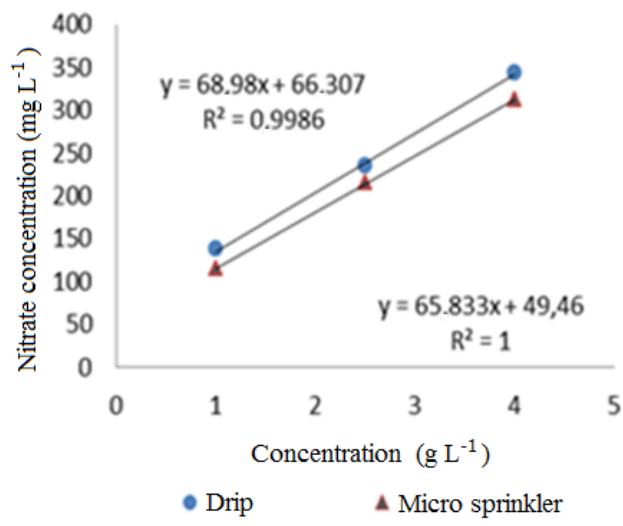

(a)

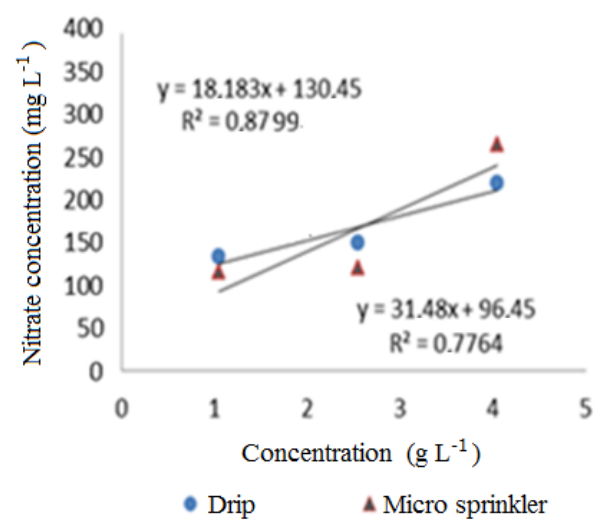

(b)

FIGURE 4. Nitrate concentration in the soil solution as a function of concentration of the injection solution to (a) $0.20 \mathrm{~m}$ and (b) $0.40 \mathrm{~m}$ depth.

The layer of $0.20 \mathrm{~m}$ presented, except for the concentration solution of $1.0 \mathrm{~g} \mathrm{~L}^{-1}$, higher concentrations of $\mathrm{NO}_{3}{ }^{-}$compared to the layer of $0.40 \mathrm{~m}$ for both the micro-sprinkler and for the 
drip. These results are expected since the process of infiltration and redistribution is more intense in the layer closest to the ground surface.

TABLE 3. NO3 $^{-}$average in soil solution at depths of 0.20 and $0.40 \mathrm{~m}$ in drip and micro sprinkler system fertirrigated with urea.

\begin{tabular}{ccccc}
\hline \multirow{2}{*}{ Urea Concentration } & \multicolumn{2}{c}{$\mathrm{NO}_{3}{ }^{-} \mathrm{mg} \mathrm{L}^{-1}(0,20 \mathrm{~m})$} & \multicolumn{2}{c}{$\mathrm{NO}_{3}{ }^{-} \mathrm{mg} \mathrm{L}^{-1}(0,40 \mathrm{~m})$} \\
\cline { 2 - 5 } & Drip & Micro & Drip & Micro \\
\hline $1.0 \mathrm{~g} \mathrm{~L}^{-1}$ & $137.50^{\mathrm{a}}$ & $115.00^{\mathrm{b}}$ & $154.45^{\mathrm{a}}$ & $142.56^{\mathrm{a}}$ \\
$2.5 \mathrm{~g} \mathrm{~L}^{-1}$ & $234.33^{\mathrm{a}}$ & $214.63^{\mathrm{b}}$ & $164.27^{\mathrm{a}}$ & $145.89^{\mathrm{b}}$ \\
$4.0 \mathrm{~g} \mathrm{~L}^{-1}$ & $344.44^{\mathrm{a}}$ & $312.0^{\mathrm{b}}$ & $209.00^{\mathrm{a}}$ & $237.00^{\mathrm{b}}$ \\
\hline
\end{tabular}

* Letters compare irrigation systems at each depth $(\mathrm{P}=0.05)$.

Statistical difference was found between the average concentrations of $\mathrm{NO}_{3}{ }^{-}$of irrigation systems at both depths ( $\mathrm{P}<0.05$ ), where drip showed higher concentration of $\mathrm{NO}_{3}{ }^{-}$in the soil solution at both depths for all urea concentrations applied in the irrigation water (Table 3). This is due to the smaller wet volume under drip which affects larger volume of solution per volume of soil in relation to micro-sprinkler, in addition to the larger root growth expected in these wet volume.

The evaluation of the $\mathrm{NO}_{3}{ }^{-}$concentration in the soil solution, resulting from fertirrigation with urea application along the crop cycle in two depths resulted in elevated levels of $\mathrm{NO}_{3}{ }^{-}$in the soil solution as the concentration of urea increased in water irrigation (Figure 5). There was no definite trend of increasing or decreasing of nitrate concentration in the soil solution with time for all concentrations of urea throughout the crop cycle for both micro sprinklers and drip. On average, the levels of $\mathrm{NO}_{3}{ }^{-}$in soil solution ranged from 137.5 to $344.4 \mathrm{mg} \mathrm{L}^{-1}$ in the drip system and from 115.0 to $312.5 \mathrm{mg} \mathrm{L}^{-1}$ for micro sprinklers in the $0.20 \mathrm{~m}$ layer. In the $0.40 \mathrm{~m}$ layer, the variations were from 154.4 to 209.0 and 142.5 to $277.0 \mathrm{mg} \mathrm{L}^{-1}$ respectively for the drip and micro sprinklers. These tracks were next to those also found by ALVES et al. (2007) who studied different combinations of urea and calcium nitrate over the same crop and obtained levels of $\mathrm{NO}_{3}{ }^{-}$in soil solution between 3.5 to $225.0 \mathrm{mg} \mathrm{L}^{-1}$ and were similar to those obtained by KAISER (2010) that obtained levels of nitrate in the soil solution between 8 to $226.0 \mathrm{mg} \mathrm{L}^{-}$. The variations obtained were higher than the range of concentrations found by MONTEIRO (2007) who studied the spatial distribution of fertilizer ions (nitrate and potassium), using solution extractors and found values between 16.0 and $171.0 \mathrm{mg} \mathrm{L}^{-1}$ for Oxisol. 

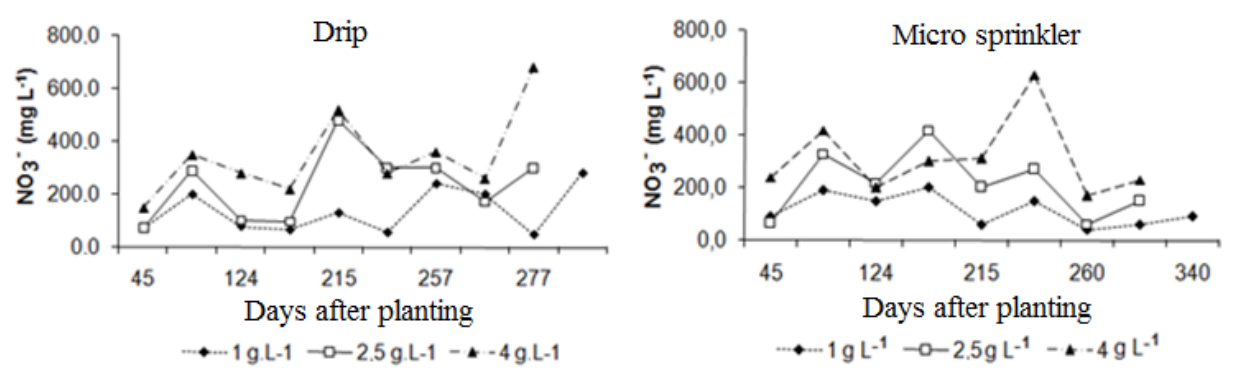

(5a)
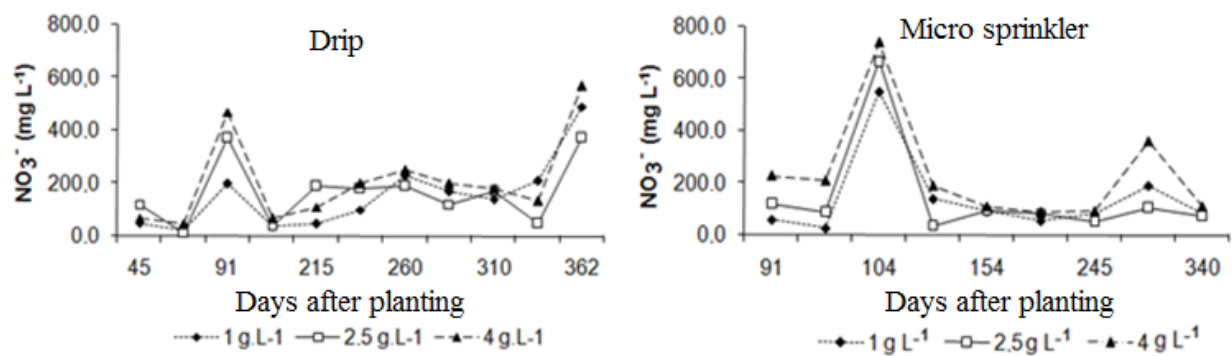

(5b)

FIGURE 5. Concentration of $\mathrm{NO}_{3}{ }^{-}$in the soil solution at depth of $0.20 \mathrm{~m} \mathrm{(5} \mathrm{a)} \mathrm{and} 0.40 \mathrm{~m} \mathrm{(5} \mathrm{b)} \mathrm{in}$ fertirrigation with urea applied in two irrigation systems (drip and spray).

No significant effect of urea concentration in irrigation water was observed on plant height, pseudo stem diameter and leaf area, and as the concentration increased, no increase was observed in growth parameters evaluated (Table 4). The leaf area reduction due to the increase of the salt levels is a common response in various banana genotypes (SILVA et al., (2009); WILLADINO et al., (2011). However for the salinity levels of the soil solution (less than $2.0 \mathrm{dS} \mathrm{m}^{-1}$ ), this reduction was not observed with increasing salt concentration in the irrigation water as a result of the treatments.

TABLE 4. Averages plant height, pseudo stem diameter and leaf area of banana cv. Terra Maranhão.

\begin{tabular}{ccccccc}
\hline \multirow{2}{*}{ Urea Concentration } & \multicolumn{2}{c}{ Height $(\mathrm{cm})$} & \multicolumn{2}{c}{ Diameter $(\mathrm{cm})$} & \multicolumn{2}{c}{ Leaf Area $\left(\mathrm{m}^{2}\right)$} \\
\cline { 2 - 7 } & Drip & Micro & Drip & Micro & Drip & Micro \\
\hline $1.0 \mathrm{~g} \mathrm{~L}^{-1}$ & $4.28^{\mathrm{a}}$ & $4.62^{\mathrm{a}}$ & $28.74^{\mathrm{a}}$ & $30.73^{\mathrm{a}}$ & $17.29^{\mathrm{a}}$ & $15.07^{\mathrm{a}}$ \\
$2.5 \mathrm{~g} \mathrm{~L}^{-1}$ & $4.31^{\mathrm{a}}$ & $4.24^{\mathrm{a}}$ & $29.94^{\mathrm{a}}$ & $29.70^{\mathrm{a}}$ & $15.52^{\mathrm{a}}$ & $17.31^{\mathrm{a}}$ \\
$4.0 \mathrm{~g} \mathrm{~L}^{-1}$ & $4.36^{\mathrm{a}}$ & $4.27^{\mathrm{a}}$ & $27.95^{\mathrm{a}}$ & $28.74^{\mathrm{a}}$ & $14.89^{\mathrm{a}}$ & $16.54^{\mathrm{a}}$ \\
\hline
\end{tabular}

* Letters compare irrigation systems on the same line $(\mathrm{p}=0.05)$.

There was effect of salt concentration on the characteristics of banana production for two used irrigation systems. The behavior of productivity as a function of concentration of irrigation water indicated that the concentration of the injection solution was different in the two irrigation systems (Figure 6), according to the concavity, but overall there was a declining trend in productivity with increasing concentration. The average productivity of treatments varied from $38.72 \mathrm{t} \mathrm{ha}^{-1}$ to $53.86 \mathrm{t} \mathrm{ha}^{-1}$ on drip, whereas treatment with $1.0 \mathrm{~g} \mathrm{~L}^{-1}$ showed higher productivity. The average productivity among irrigation systems did not differ for the concentration of $1.0 \mathrm{~g} \mathrm{~L}^{-1}$ (Table 5), the concentration of $2.5 \mathrm{~g} \mathrm{~L}^{-1}$ showed higher productivity, although with value closes to concentration of $1.0 \mathrm{~g} \mathrm{~L}^{-1}$ for treatments applied through micro sprinkler. 


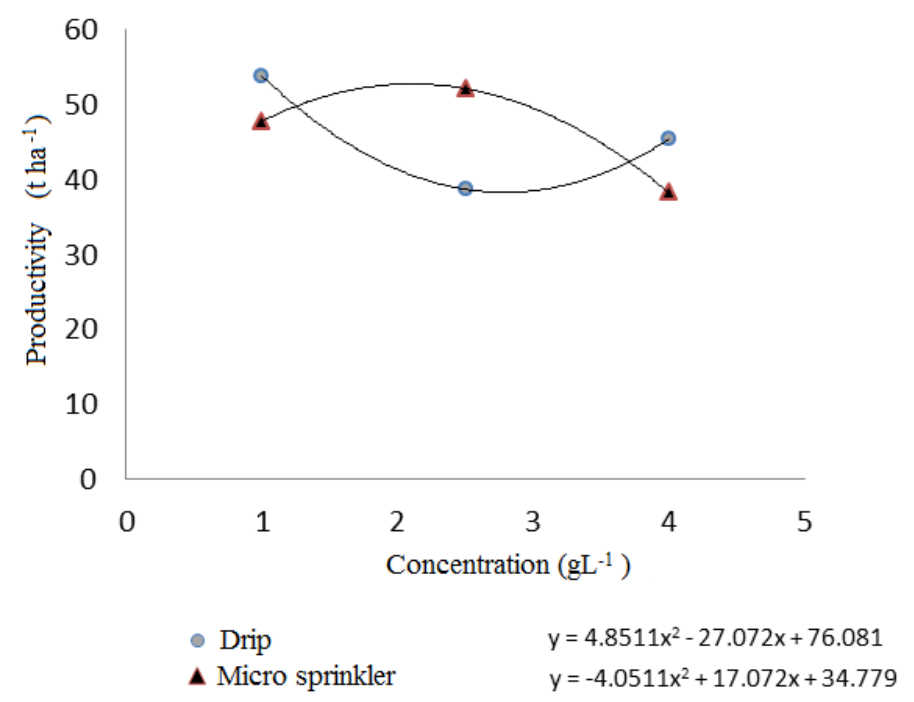

FIGURE 6. Productivity of banana cv. Terra Maranhão as a function of concentration of the injection solution.

The results are in agreement with those found by MEDEIROS et al (2008), who observed differences in productivity with increasing salt concentration in the irrigation water. There was no effect of concentration of the injection solution in production variables, length and diameter of the median fruit from the second hand (Table 5), which was also observed by ANDRADE NETO et al. (2011). These variables (length and fruit diameter) were not affected by the irrigation system (Table 5).

TABLE 5. Average productivity, length and diameter of the fruit of the banana cv. Terra Maranhão.

\begin{tabular}{ccccccc}
\hline Urea Concentration & \multicolumn{2}{c}{$\begin{array}{c}\text { Productivity } \\
\left(\mathrm{t} \mathrm{ha}^{-1}\right)\end{array}$} & \multicolumn{2}{c}{$\begin{array}{c}\text { The fruit length in the } \\
\text { second bunch }\end{array}$} & $\begin{array}{c}\text { Average fruit diameter of } \\
\text { the second bunch }\end{array}$ \\
\cline { 2 - 6 } & Drip & Micro & Drip & Micro & Drip & Micro \\
\hline $1.0 \mathrm{~g} \mathrm{~L}^{-1}$ & $53.86^{\mathrm{a}}$ & $47.0^{\mathrm{a}}$ & $26.50^{\mathrm{a}}$ & $23.50^{\mathrm{a}}$ & $42.25^{\mathrm{a}}$ & $39.50^{\mathrm{a}}$ \\
$2.5 \mathrm{~g} \mathrm{~L}^{-1}$ & $38.72^{\mathrm{b}}$ & $52.14^{\mathrm{a}}$ & $24.00^{\mathrm{a}}$ & $23.75^{\mathrm{a}}$ & $36.50^{\mathrm{a}}$ & $35.75^{\mathrm{a}}$ \\
$4.0 \mathrm{~g} \mathrm{~L}^{-1}$ & $45.41^{\mathrm{a}}$ & $38.25^{\mathrm{b}}$ & $23.75^{\mathrm{a}}$ & $23.00^{\mathrm{a}}$ & $39.50^{\mathrm{a}}$ & $35.65^{\mathrm{a}}$ \\
\hline
\end{tabular}

* Letters compare irrigation systems on the same line $(\mathrm{p}=0.05)$.

\section{CONCLUSIONS}

Urea can be used in concentrations up to $2.5 \mathrm{~g} \mathrm{~L}^{-1}$ in irrigation water without causing increases in electrical conductivity of the soil solution and the saturation extract above the amount considered appropriate for the crop $1.1 \mathrm{dS} \mathrm{m}^{-1}$.

As the concentration of the injection solution increases, the concentration of $\mathrm{NO}^{-}$increases significantly in the soil solution with maximum at concentrations of $4.0 \mathrm{~g} \mathrm{~L}^{-1}$.

The concentrations of urea in the injection solution has no effect on the pseudo stem diameter and height of the plant, as well as on length and diameter of the fruit of second hand, but has effect on productivity.

\section{REFERENCES}

ALVES, M. S.; COELHO, E. F.; PAZ, V. P. S.; ANDRADE NETO, T. M.. Crescimento e produtividade da bananeira cv. Grande Naine sob diferentes combinações de nitrato de cálcio e ureia. Revista Ceres, Viçosa, MG, v. 57, p. 125. 2010.

ALVES, M. S.; COELHO, E. F.; LÊDO, C. A. S.; ANDRADE NETO, T. M.; SANTANA, J. A. V.; SANTANA JUNIOR, E. B. Concentração do íon $\mathrm{NO}_{3}{ }^{-}$no solo sob diferentes combinações de 
fontes nitrogenadas via fertirrigação em bananeira no segundo ciclo de produção. In: Workshop, MANEJO E CONTROLE DA SALINIDADE NA AGRICULTURA IRRIGADA, 2007, Recife. Anais... Recife: UFRPE, 2007. CD-ROM.

ANDRADE NETO, T. M.; COELHO, E. F.; ALVES, M da S.; SANTANA JUNIOR, E. B.; SANTANA, J. A do. Estimating potassium in the soil solution as a function of electrical conductivity and soil water content. Revista Brasileira de Engenharia Agrícola e Ambiental, Campina Grande, v. 16, n. 6, 2012. Disponível em:

<http://www.agriambi.com.br/revista/v16n06/v16n06a05.pdf>. Acesso em 20 set 2012.

ANDRADE NETO, T. M.; COELHO, E. F.; SILVA, A. J; SILVA, A. C. P. Efeito da aplicação de diferentes fontes fertilizantes via fertirrigação na qualidade de frutos de bananeira. In:

CONGRESSO BRASILEIRO DE ENGENHARIA AGRÍCOLA, 40. 2011, Cuiabá. Anais... Cuiabá: Geração de Tecnologias Inovadoras e o Desenvolvimento do Cerrado Brasileiro, 2011.

BLANCO, F.F.; FOLEGATTI, M.V.; GHEYI,H.R.; FERNANDES, P.D.

Growthandyieldofcornirrigatedwith saline water. Scientia Agrícola, Piracicaba, v.65, n.6, p.574580, 2008.

COELHO, E. F.; COSTA, F. da S.; SILVA, A. C. P. da.; CARVALHO, G. C. Concentração de nitrato no perfil do solo fertirrigado com diferentes concentrações de fontes nitrogenadas. Revista Brasileira de Engenharia Agrícola e Ambiental. Campina Grande, v.18, n.3, p.263-269, 2014.

COELHO, E. F.; BORGES, A. L.. Aspectos básicos da fertirrigação. In: Borges, A.L.; Coelho,E.F. (Org.). Fertirrigação em fruteiras tropicais. 2. ed. Cruz da Almas: Embrapa Mandioca e Fruticultura, 2009. v. 1, p. 9-19.

COSTA, S. F.; COELHO, E. F.; Carvalho, G.C. Condutividade Eletrica do solo Sob Fertiirigação com Diferentes Concentrações de Uréia e Nitrato de potássio na bananeira Terra. XXXII CONGRESSO BRASILEIRO DE CIÊNCIA DO SOLO, 32, 2009, Fortaleza. Anais... Fortaleza: O Solo e a Produção de Bioenergia: Perspectivas e Desafios, 2009.

DIAS, N. D.; BLANCO, F. F. Efeitos dos sais no solo e na planta. In: GHEYI, H. R.; DIAS, N. S.; LACERDA, C. F. Manejo da salinidade na agricultura: estudos básicos e aplicados. Fortaleza: Instituto Nacional de Ciência e Tecnologia em Salinidade, 2010. p. 129-140.

DOORENBOS, J.; KASSAM, A.H. Efeito da água no rendimento das culturas. Campina Grande: UFPB, 1994. 306p. (FAO. Irrigação e Drenagem, 33).

EMBRAPA. Manual de métodos de análise de solo. Rio de Janeiro: Centro Nacional de Pesquisa de Solo, 1997. 212 p.

FAGERIA, N. K.; SOARES Filho, W. S.; GHEYI, H. R. In: GHEYI, H. R.; Dias, N. S.; LACERDA, C. F. (Ed.). Manejo da salinidade na agricultura. Fortaleza: INCT Sal, 2010. p.206217.

GHEYI, H. R.; DIAS, N. da S.; LACERDA, C. F. Manejo da salinidade na agricultura: Estudos básicos e aplicados. Fortaleza: INCT Sal, 2010. 472p.

ISRAELI, Y.; LAHAY, E.; NAMERI, N. The effect of salinity and sodium adsorption ratio in the irrigation water on growth and productivity of bananas under drip irrigation conditions. Fruits, Paris, v.41. p.297-302, 1986.

KAISER, D. R.; BRAGA, F. V. A.; REINERT, D.J.; REICHERT, J.M.; AITA, C. Nitrato e amônio na solução do solo em sistemas de manejo para cultura do fumo. Revista Brasileira de Ciência do Solo, Viçosa, MG, v.34, n.2, p.379-388, 2010.

MEDEIROS, J. F.; CARMO, G. A.; GONDIM, A. R. O.; TAVARES, J. C. Produção de duas cultivares de bananeira submetidos a diferentes níveis de salinidade de água de irrigação. Revista Ciência Agronômica, Fortaleza, v 39, n. 3, p. 362-368, 2008. 
MONTEIRO, R. O. C. Influência do gotejamento subterrâneo e do "mulching” plástico na cultura do melão em ambiente protegido. 2007. 178f. Tese (Doutorado em Agronomia)- Escola Superior de Agricultura Luiz de Queiroz, Universidade de São Paulo, Piracicaba, 2007.

OLIVEIRA, S. O. de. Irrigação e Fertirrigação. In: Zilton José Maciel Cordeiro. (Org.). Banana. Produção: aspectos técnicos.. 1ed.Brasília, DF: Embrapa, 2000, v. 1, p. 60-73.

OLIVEIRA, S. O. de; ALVES, E. J.; SHEPHERD, K.; DANTAS, J. L. L. Cultivares. In: ALVES, E. J. (Org.) A cultura da banana: aspectos técnicos, socioeconômicos e agroindustriais. 2.ed. Brasília: Embrapa-SPI, Cruz das Almas: Embrapa-CNPMF, 1999. p.85-105

SANTANA, G. DA S., COELHO, E. F., SILVA, T. S. M. da, RAMOS, M. M. Estimativa da condutividade elétrica da solução do solo a partir do teor de água e da condutividade elétrica aparente do solo. Revista Engenharia Agrícola, Jaboticabal, v.26, n.3, p.672-685, 2006.

SILVA, R. L. O.; MARTINS, L. S. S.; GOMES, E. W. F.; FERRAZ, G. M. G.; SILVA, S. O.; WILLADINO, L. Avaliação de diplóides de bananeira (Musa spp.) quanto à tolerância a salinidade. Revista Brasileira de Fruticultura, Jaboticabal, v.31, p.1084-1091, 2009.

TAIZ, L.; ZEIGER, E. Fisiologia vegetal. Porto Alegre: Ed Artmed, 2009. 848 p.

WILLADINO, L.; GOMES, E. W. F.; SILVA, E. F. F.; MARTINS, L. S. S.; CAMARA, T. R. Efeito do estresse salino em genótipos tetraplóides de bananeira. Revista Brasileira de Engenharia Agrícola e Ambiental, Campina Grande, v.15, p.53-59, 2011. 